\title{
THE ASSESSMENT OF EFFECTIVENESS OF BLAST FURNACE USING PAMCO METHOD
}

\author{
Edyta KARDAS ${ }^{1}$, Andrzej SKOWRONEK ${ }^{2}$ \\ ${ }^{1}$ Czestochowa University of Technology, Czestochowa, Poland, EU, edyta.kardas@pcz.pl \\ ${ }^{2}$ Cracow University of Technology, Kraków, Poland, EU, andrzej.skowronek@pk.edu.pl
}

https://doi.org/10.37904/metal.2021.4304

\begin{abstract}
One of the basic factors influencing the good results of any production system is the optimal organization of the production process so that the use of machines is as effective as possible. One of the methods of assessing the use of machine working time is the PAMCO (Project Analysis and Monitoring Company) method. The main goal of the paper is the presentation of results of PAMCO method of blast furnace working in one of Polish steelworks. The analysis includes data related to different types of time for calculating appropriate indexes. The analysis covers the period of one calendar year.
\end{abstract}

Keywords: Blast furnace, pig iron, effectiveness, PAMCO method

\section{INTRODUCTION}

Blast furnace process is the basic manufacturing process of pig iron and the first step in steel production chain. It is a device which works continuously. Blast furnace process is very complex and involves enormous streams of materials and energy. There are many factors influencing the production costs, among them are: the use of well-prepared and high-quality materials and fuels, maintenance of parameters of blast furnace process at the optimum level and the most efficient use of working time of the installation [1]. The paper focused on the working time of selected blast furnace device. Analysis of efficiency of working time should be divided into two parts: Overall Equipment Effectiveness - OEE and PAMCO. The results of OEE analysis was presented in other work [2]. The main goal of this paper is the presentation of results of PAMCO method of blast furnace conducted in one of Polish steelworks. The analysis includes data related to different types of time for calculating appropriate indexes. The analysis covers the period of one calendar year.

The methodology presented here can be applied in many ways when it comes to the use of expensive machines, the working time of which should be monitored and optimized. These are both industrial (e.g. automotive [3,4], lean management [5,6], logistic [7], quality [8,9], food production [10]) and service (e.g. databases [11], intelligent buildings [12], e-commerce [13] and education [14]), but also research-laboratory (e.g. protective coatings [15,16], surface machining [17,18], fatigue analysis [19] and biotechnology [20,21]) areas. The analysis carried out and the results obtained may also be inspiring for researchers using similar analytical methodologies (e.g. risk management [22] or knowledge management [23]).

\section{PAMCO - METHODOLOGY OF THE RESEARCH}

One of the basic goals of any enterprise is the optimal use of its resources. To assess their use, one can use many technical and economic indicators, which include, among others, productivity or efficiency. One of the methods used to assess the efficiency of machines and equipment is PAMCO. The PAMCO method is used to measure the performance of machines and is based on indicators that are defined based on the time structure [24]. The PAMCO method shows the measurement values and reports the operation of machines and technical devices. This method also determines the working time of the tested devices, reduces the 
number of parameters used, giving a picture of the measurement of these devices [25]. Time, according to the PAMCO method, was divided into types presented in Table 1.

Table 1 Activities and events included in the individual types of times and ways of calculating $[25,26]$

\begin{tabular}{|c|c|c|}
\hline Calcucated time & Components. Time calculation formulas & $\begin{array}{l}\text { Components included in the } \\
\text { analysis of the operation of blast } \\
\text { furnaces }\end{array}$ \\
\hline $\mathrm{TT}$ - total time & $\begin{array}{c}\text { Total time, number of hours covering the } \\
\text { study period }\end{array}$ & $\begin{array}{c}\text { Total number of hours for blast furnace } \\
\text { under study }\end{array}$ \\
\hline UAT - unavailable time & $\begin{array}{c}\text { Free time related to holidays, and free } \\
\text { weekends }\end{array}$ & $\begin{array}{c}\text { As the devices work in a continuous } \\
\text { system, this time is } 0\end{array}$ \\
\hline AT - available time & \multicolumn{2}{|c|}{ AT $=$ TT - UAT } \\
\hline $\begin{array}{l}\text { AUT - available but unused } \\
\text { time }\end{array}$ & $\begin{array}{c}\text { Number of hours associated with downtime } \\
\text { due to lack of orders, autonomous } \\
\text { maintenance }\end{array}$ & $\begin{array}{c}\text { Number of hours for blast furnaces } \\
\text { doe to the lack of receipt of pig iron or } \\
\text { no materials (sinter and coke) }\end{array}$ \\
\hline UT - utilization time & \multicolumn{2}{|c|}{ UT $=$ AT - AUT } \\
\hline $\begin{array}{c}\text { PNOT - planned } \\
\text { nonoperational time }\end{array}$ & $\begin{array}{l}\text { Number of hours related to changes in plans, } \\
\text { technological trials, repairs }\end{array}$ & $\begin{array}{l}\text { Standstill times of blast furnaces } \\
\text { related to repairs }\end{array}$ \\
\hline OT - operational time & \multicolumn{2}{|c|}{ OT = UT - PNOT } \\
\hline Routine stops, rps & $\begin{array}{c}\text { Number of hours related to routine stops for: } \\
\text { cleaning, assortment changes, production } \\
\text { stoppages and losses, routine machine } \\
\text { changes }\end{array}$ & $\begin{array}{c}\text { Number of hours of operation of blast } \\
\text { furnaces related to technological and } \\
\text { mechanical breaks }\end{array}$ \\
\hline PT - production time & \multicolumn{2}{|c|}{$\mathrm{PT}=\mathrm{OT}-\mathrm{rps}$} \\
\hline Unplanned stops, us & $\begin{array}{l}\text { Hours of unplanned downtime: minor stops, } \\
\text { breakdowns, adjustments, errors, decreased } \\
\text { machine performance, technological } \\
\text { problems, logistic disruptions }\end{array}$ & $\begin{array}{c}\text { Unplanned breaks in the operation of } \\
\text { blast furnaces related to electrical and } \\
\text { energy breaks, power limitation and } \\
\text { others }\end{array}$ \\
\hline ET - effective time, ET & \multicolumn{2}{|c|}{$\mathrm{ET}=\mathrm{PT}-\mathrm{us}$} \\
\hline
\end{tabular}

Individual types of times were used to calculate indicators that give a complete and clear picture of the use of the machine's work [24-26]:

1) Production Efficiency (PE)

$P E=\frac{E T}{P T} \cdot 100 \%$

2) Operational Efficiency (OE)

$O E=\frac{E T}{O T} \cdot 100 \%$

3) Available Utilization (AU)

$A U=\frac{O T}{A T} \cdot 100 \%$

4) Asset Availability (AA)

$A A=\frac{A T}{T T} \cdot 100 \%$

5) Asset Utilization (AUt),

$A U T=\frac{U T}{T T} \cdot 100 \%$

6) Operational Utilization (OU)

$O U=\frac{O T}{T T} \cdot 100 \%$

7) Production Utilization (PU)

$P U=\frac{P T}{T T} \cdot 100 \%$ 
8) Effective Utilization (EU),

$E U=\frac{E T}{T T} \cdot 100 \%$

Optimum values of indicators in the PAMCO methods should reach the following optimum [24-26]:

- PE - as high as possible and exceed value of approximately $95 \%$,

- OE - about $92.5 \%$,

- AU - about $90 \%$,

- AA - about $97 \%$,

- AUt - it is required that it takes value of $65 \%$,

- OU - about $62 \%$,

- PU - exceed $60 \%$,

- EU - at level $50 \%$.

Research was conducted in one of Polish steelworks. One blast furnace was selected. The analysis covers the monthly data of the period of one calendar year. During the analysis, on the beginning the information about the work of the device was collected, then main indicators were calculated according to the Table 1 formulas (1) - (8). Values were compared to the average and optimum values.

\section{THE ANALYSIS OF RESULTS}

Analysis of PAMCO indicators for blast furnace device was conducted. Values of basic indicators were calculated according to gathered data and were compared to the average values in the study period. Results of this analysis are presented in Figures 1-7.

The PAMCO analysis conducted for the selected blast furnace device (Figures 1-7) allowed for the conclusion that:

- $\quad$ Production Efficiency (PE) indicates what part of the production time is the effective time (less unplanned stops). The average value of the index was approx. 99.6\%. In four months it was lower than the average, the lowest value was recorded in July. It was caused mainly by energetic breaks. However, this indicator was still at a high level and exceeded the optimal value (95\%).

- Operational Efficiency (OE) indicates what part of the operational time is effectively used during the manufacturing process, and what part of this time are interruptions related to routine and unplanned stops. The average value of this indicator was over $98.4 \%$ and remained at a similar, high level for almost the entire period, the lowest value was recorded months 7,812 , what was caused mainly by technological breaks. The values for the entire period exceeded the optimal value of $92.5 \%$.

- $\quad$ Available Utilization $(\mathrm{AU})$ defines the percentage of operational time in the available time (planned nonoperational time is taken into account) and its value should be at least $90 \%$. During the study period, the average value of over $88 \%$ was obtained, slightly below the optimal value. The lowest values were recorded in months 3 and 9-11, which was related to the planned current repairs of the device.

- Asset Availability (AA) is the percentage of available time in total time, and it should be at level of minimum $97 \%$. Because the blast furnace device work continuously, value of this indicator is $100 \%$. 


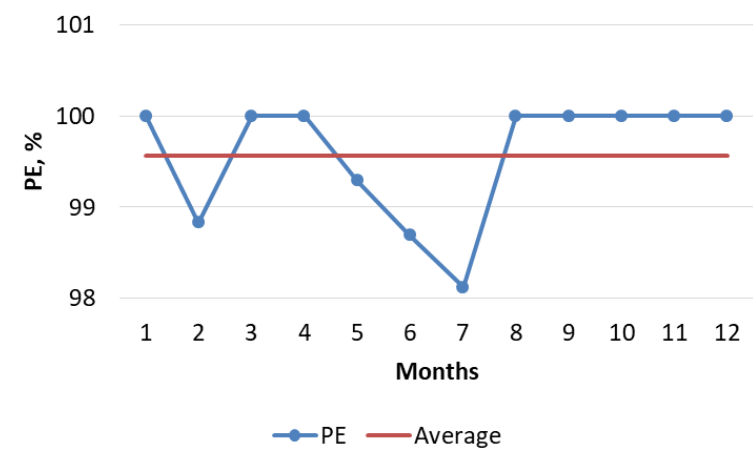

Figure 1 Value of Production Efficiency (PE) in comparison to the average value in the study period (Own study based on [27])

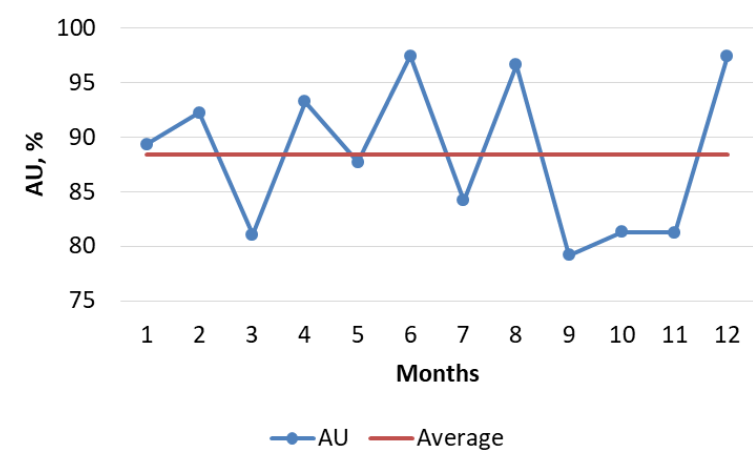

Figure 3 Value of Available Utilization (AU) in comparison to the average value in the study period

(Own study based on [27])

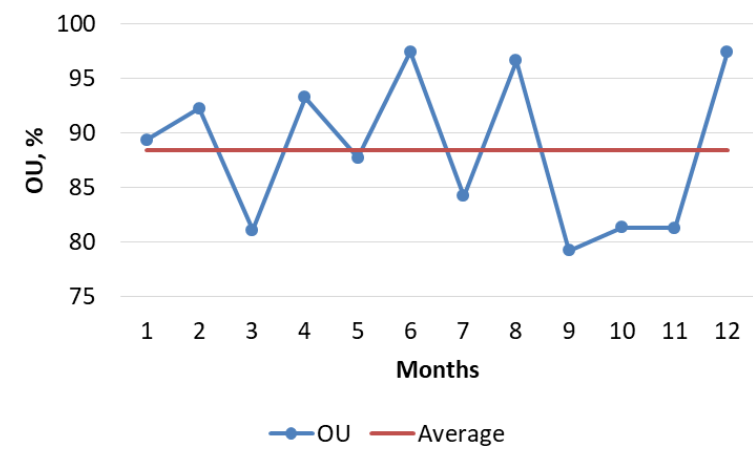

Figure 5 Value of Operational Utilization (OU) in comparison to the average value in the study period

(Own study based on [27])

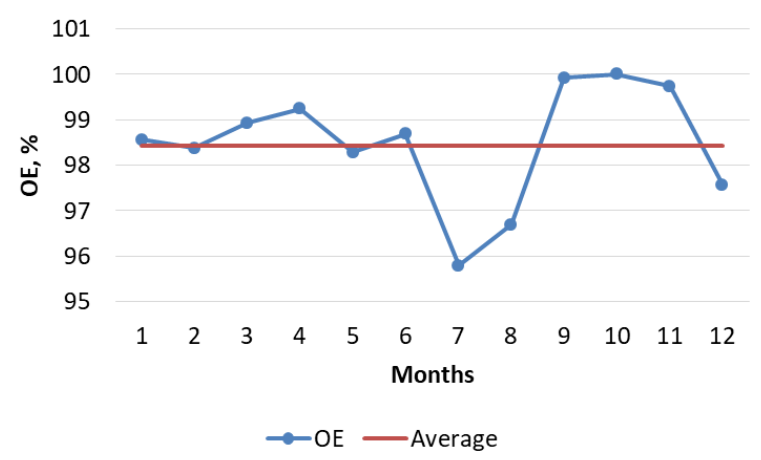

Figure 2 Value of Operational Efficiency (OE) in comparison to the average value in the study period

(Own study based on [27])

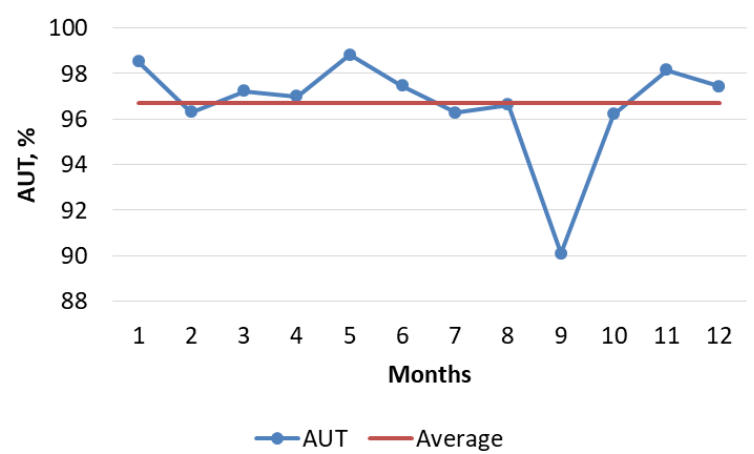

Figure 4 Value of Asset Utilization (AUt) in comparison to the average value in the study period

(Own study based on [27])

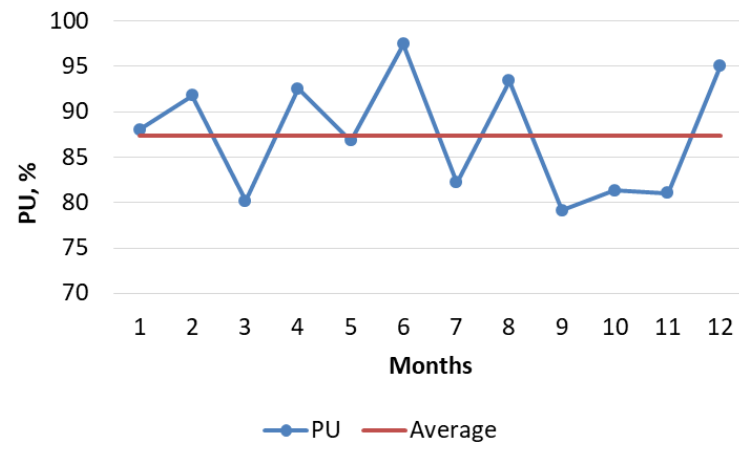

Figure 6 Value of Production Utilization (PU) in comparison to the average value in the study period

(Own study based on [27])

- $\quad$ Asset Utilization (AUT) shows how much of the total time is used, and how much of that time is downtime due to lack of orders or material. The average value of this indicator was above $96 \%$. In this case, value below the average was recorded in month 9 . Throughout the entire period, the optimal value (65\%) was exceeded.

- $\quad$ Production utilization (PU) indicates what part of the total time is the production time and what part of the time is spent on interruptions related to the available unused time, repairs and routine stops. The 
average value of this indicator throughout the period was over $87 \%$, and it significantly exceeded the optimal value of $60 \%$. In months $2,9-11$ it was well below the average due to significant downtime in the operation of the machine.

- $\quad$ Production utilization $(\mathrm{OU})$ was on the same level as $A U$, since the bases of reference in both indicators (time available for $\mathrm{AU}$ and total time for $\mathrm{OU}$ ) are the same. The optimal value was significantly exceeded.

The indicator of effective utilization EU (average level of approx. 87\%) usually significantly exceeded the requirements $(50 \%)$, which proves the good organization of production and optimal use of blast furnace working time. Moreover, the values of this indicator were very close to the PU indicator.

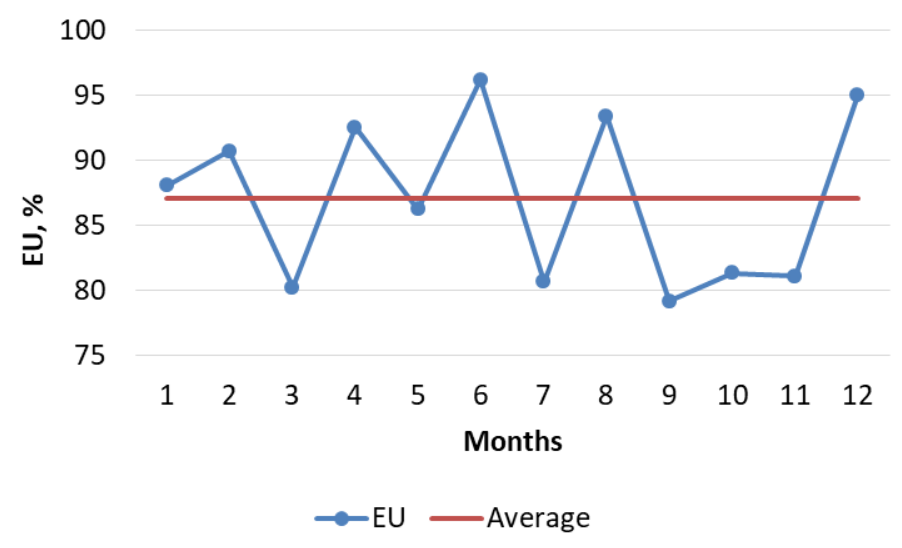

Figure 7 Value of Effective Utilization (EU) in comparison to the average value in the study period (Own study based on [27])

\section{CONCLUSION}

Conducting continuous evaluation of efficiency of working time of machines is very helpful for all organization, because it allows assessing current situation, identify factors, which should be improved, and optimize their work. Many various methods can be used in such situation, one of them is PAMCO. In this work the analysis was conducted for selected blast furnace device working in one of Polish steelworks. The results show that main indicator of this analysis is on very high level and exceeds the minimum values what proves the high efficiency of working. In case of blast furnace many factors can influence on the values of indicators: situation on the steel market in Poland and the world, demand for raw materials, work organization of blast furnace, number of repairs, length of breaks and stops, way of working of device. Such analysis should be done continuously, and the results should be compared with similar devices that work in other steel plants.

\section{REFERENCES}

[1] SABELA W., BRZEZIŃSKI P., BUZEK J. Factors affecting the cost of obtaining of metallic iron. Hutnik Wiadomości Hutnicze. 2005, vol. 72, no. 10, pp. $490-496$.

[2] KARDAS E. The application of the OEE method for the assessment of blast furnace effectiveness, In: METAL 2020, 29th Int. Conf. on Metall. and Mater. Ostrava: TANGER, 2020, pp. 1315-1320.

[3] PACANA A., CZERWIŃSKA K., BEDNAROWA L.. Comprehensive improvement of the surface quality of the diesel engine piston. Metalurgija. 2018. vol. 58, pp. 329-332.

[4] CZERWIŃSKA, K., DWORNICKA, R., PACANA, A. Improvement of the surface of the combustion chamber of a piston using selected techniques of production organization. Materials Research Proceedings. 2020, vo. 17, pp. $270-275$.

[5] ANTOSZ, K., PACANA, A. Comparative analysis of the implementation of the SMED method on selected production stands. Tehnicki Vjesnik. 2018, vol. 25, pp. 276-282. 
[6] MASZKE, A., DWORNICKA, R., ULEWICZ, R. Problems in the implementation of the lean concept at a steel works - Case study. MATEC Web of Conf. 2018, vol. 183, art. 01014.

[7] ULEWICZ, R., MAZUR, M., KNOP, K., DWORNICKA, R. Logistic controlling processes and quality issues in a cast iron foundry. Materials Research Proceedings. 2020, vol. 17, pp. 65-71.

[8] PIETRASZEK, J., GOROSHKO, A. The heuristic approach to the selection of experimental design, model and valid pre-processing transformation of DoE outcome. Adv. Mater. Res.-Switz. 2014, vol. 874, pp. 145-149.

[9] PACANA, A., CZERWIŃSKA, K., DWORNICKA, R. Analysis of non-compliance for the cast of the industrial robot basis. In: METAL 2019: $28^{\text {th }}$ Int. Conf. on Metall. and Mater. Ostrava: TANGER, 2019, pp. 644-650.

[10] BARYSHNIKOVA, N., KIRILIUK, O., KLIMECKA-TATAR, D. Management approach on food export expansion in the conditions of limited internal demand. Polish J. Manage. Stud. 2020, vol. 21, pp.101-114.

[11] KARPISZ, D., KIEŁBUS, A. Implementation of fuzzy logic in industrial databases. Materials Research Proceedings. 2020, vol. 17, pp. 100-107.

[12] MAJEWSKI, G., ORMAN, Ł.J., TELEJKO, M., RADEK, N., PIETRASZEK, J., DUDEK, A. Assessment of thermal comfort in the intelligent buildings in view of providing high quality indoor environment. Energies. 2020, vol. 13, art. 1973.

[13] INGALDI, M., ULEWICZ, R. Evaluation of quality of the e-commerce service. Int. J. Ambient Comput. Intell. 2018, vol. 9, pp. 55-66.

[14] ULEWICZ, R. Application of servqual method for evaluation of quality of educational services at the university of higher education. Polish J. Manage. Stud. 2014, vol. 9, pp. 254-264.

[15] GUIDONI, G., DUDEK, A., PATSIAS, S., ANGLADA, M. Fracture behavior of thermal barrier coatings after high temperature exposure in air. Mater. Sci. Eng. A. 2005, vol. 397, pp. 209-214.

[16] RADEK, N., KONSTANTY, J. Cermet ESD coatings modified by laser treatment. Arch. Metall. Mater. 2012, vol. 57, pp. 665-670.

[17] MICHNA, S., NAPRSTKOVA, N., KLIMECKA-TATAR, D. Research the causes of surface stains after eloxal coating for the profile from the AIMgSi alloy using substructural analysis. Manuf. Technol. 2015, vol. 15, pp. 620624.

[18] LIPINSKI, T. Influence of surface refinement on microstructure of AI-Si cast alloys processed by welding method. Manuf. Technol. 2015, vol. 15, pp. 576-581.

[19] ULEWICZ, R., NOVÝ, F., SELEJDAK, J. Fatigue strength of ductile iron in ultra-high cycle regime. Adv. Mater. Res.-Switz. 2014, vol. 874, pp. 43-48.

[20] SKRZYPCZAK-PIETRASZEK, E., SKRZYPCZAK, L., WESOLOWSKA, M. Gentiana tibetica King from tissue culture. Scientia Pharmaceutica. 1993, vol. 61, pp. 287-296.

[21] SKRZYPCZAK-PIETRASZEK, E., URBANSKA, A., ZMUDZKI, P., PIETRASZEK, J. Elicitation with methyl jasmonate combined with cultivation in the Plantform ${ }^{\mathrm{TM}}$ temporary immersion bioreactor highly increases the accumulation of selected centellosides and phenolics in Centella asiatica (L.) Urban shoot culture. Engineering in Life Sciences. 2019. vol. 19, pp. 931-943.

[22] KOZIEN, E., KOZIEN, M.S. The EX ante risk assessment in the project in interval analysis description. Materials Research Proceedings. 2020, vol. 17, pp. 31-35.

[23] ULEWICZ, R., BLASKOVA, M. Sustainable development and knowledge management from the stakeholders' point of view. Polish J. Manage. Stud. 2018, vol. 18, pp. 363-374.

[24] BORKOWSKI S., ULEWICZ R. Production management. Production systems. Sosnowiec: Printing House „Humanitas”, 2009.

[25] INGALDI M. Zastosowanie metody PAMCO do oceny efektywności walcowni. Hutnik-Wiadomości Hutnicze. 2021, vol. 83, no 11, pp. 517-519.

[26] KARDAS E. Ocena wykorzystania czasu pracy wielkich pieców przy użyciu metody PAMCO. Hutnik-Wiadomości Hutnicze. 2012, vol. 79, no 12, pp. 852-855

[27] Information materials, 2019. Blast Furnace Department of Steelworks X. 